\title{
Occurrence of Stored Grain Insect Pests in Traditional Underground Pit Grain Storages of Eastern Ethiopia
}

\author{
Tadeos Shiferaw* \\ Department of Dryland Crop Sciences, Collage of Dryland Agriculture, Ethiopia
}

Submission: September 10, 2017; Published: January 09, 2018

"Corresponding author: Tadeos Shiferaw, Department of Dryland Crop Sciences, Collage of Dryland Agriculture, Jigjiga University, P.O. B0X 1020, Jigjiga, Ethiopia, Email: tadu1352@gmail.com

\begin{abstract}
Grain samples were collected from 179 on-farm traditional pit stores found in four districts of Ethiopian Somali provenance namely Babille, Gurusm, Jigjiga and Awubarre. The study was conducted to assess the occurrence and damage related to storage insect pests in traditional pit grain storage system. Data on relative abundance, insect grain damage and germination percentage for each district were summarized and subjected to analysis. According to the result, all assessed grain stores exhibited with significant infestation with storage insect pests. Over all finding indicted that maize weevil ( $S$ zeamais), Angoumois grain moth (S cerealella) with mean relative abundance of 41.25 and $28.52 \%$ respectively others including flour beetle ( $T$ castenum), flat grain beetles ( $C$ ferugineus) and Saw-toothed grain beetle $(O$ surinamensis $)$ were also commonly recorded in significant abundance. Maximum grain damage in sorghum was recorded from Awubarre district 29.27\%. The highest grain damage in maize was recorded in Babile 33.88, Gursum 32.47 and Jigiga 30.86\%. Sorghum and maize grain stored for at least 8-9 month showed mean germination percentage of $72.81 \%$ and $66.96 \%$ respectively.
\end{abstract}

Keywords: Stored grain; Insect pests; Pit storage system

\section{Introduction}

Post-harvest losses are one of the major causes of food insecurity in the developing world. In Africa, at the farm level, producers store their grains for three purposes: for consumption until the next harvest, as seed for planting in the next season and for selling when prices become favorable. In many developing countries, including in Ethiopia, grain storage practices involve traditional structures, which are largely ineffective in the prevention of deterioration of stored products [1]. The majority of framers in Ethiopia (93.3\%) use traditional storage containers that exposes stored grains to storage insect pest, mold and other lose factors [2].

Among the key constraints to improving food security in Africa are losses resulting from poor post-harvest management of grains [3]. The average grain losses due to storage pests about $12 \%$ of the total grain produced in some case the losses could be rise to $50 \%$ [4]. Deterioration of stored grains results from the interactions of several factors such as physical, chemical and biological variables existing the overall chains from production to consumptions [2]. Deterioration of grain due to infestations of insects, mites, and fungi is the main post-harvest factor affecting the nutritional quality and marketability of stored grain.
Grain storage pests are major concerns for farmers worldwide but especially in developing countries because large percentage of the crop may be lost to storages pests. Prior to any pest control interventions it is vital to assess the pest status and extent of losses that have occurred or likely to occur during storage [5].

In Ethiopia studies on grain postharvest storage management practice and associated storage pest are limited to other parts of the country. Information on the occurrence and distribution of stored grain insect pests in common traditional grain store is lacking. The absence of documented information has made difficult to design and implement intervention strategies in the region. Therefore, current study was intended to find out occurrence and distribution of stored grain insect pests in onfarm traditional underground pit grain stores in agro pastoralist villages in Eastern Ethiopia.

\section{Materials and Methods}

\section{Description of study area}

Data was collected from four randomly selected districts of Eastern Ethiopia namely Babile, Gursum, Awu-barre and Jigjiga. 
These districts are located $9-11^{\circ} \mathrm{N} 42-43^{\circ} \mathrm{E}$ and climate is largely influenced by its proximity to the Gulf of Aden in the north and the Indian Ocean in the East. The area has Bi-modal rainfall pattern with total annual rainfall ranging from $193.1 \mathrm{~mm}$ to 756 $\mathrm{mm}$ and average annual temperature of $15.3^{\circ} \mathrm{C}$ to $24.9{ }^{\circ} \mathrm{C}$ [6].

\section{Methods of data collection}

Study was conducted in June-August 2015 on randomly selected 179 traditional underground pit grain stores. Grain samples were collected from storage system found in four districts indicted below in the map. From each stores $100 \mathrm{~g}$ of maize and sorghum grain samples were collected in three different depth of the store (from the surface, midway and near bottom) then samples were bulked and then $300 \mathrm{~g}$ sample prepared as sample/each stores. Then samples were tagged and brought to Jigjiga University Dryland Crop Science laboratory for analysis.

\section{Laboratory analysis}

Storage insect pest species identification: Insect pest species were identified after separation of grain debris, suspected grain samples were placed in an incubator adjusted to function $+27{ }^{\circ} \mathrm{C}$ for ten days till the adult emerges from the infested seed. Finally insect samples collected from grain and observed under dissecting microscope under $20^{\mathrm{x}}$ magnification. After observation identification storage insect species were made based on the identification guide presented in [7].

Relative abundance of insect pests: Relative abundance of each storage insect pest determination was performed after insect pastes were identified and counted from grain samples collected from grain stores of four districts

Relative abundance $=$ Number of individual insect species in the sample $\mathrm{x} 100$ Total insect species in the sample

Physical grain damage due to insects: three hundred seed of sorghum and maize were randomly taken form grain samples collected from four districts then each sample were divided in to three parts finally number of damaged grain was counted manually using hand lens then percent of damaged grain was

Table 1: Relative abundance of recorded storage insect pests in traditional underground pit grain stores.

\begin{tabular}{|c|c|c|c|c|c|}
\hline \multirow[t]{2}{*}{ Districts } & \multicolumn{5}{|c|}{ Grain Storage Insect Pests Relative Abundance Across Districts } \\
\hline & $\begin{array}{c}\text { S zeamais } \\
\text { (Curculionidae) }\end{array}$ & $\begin{array}{c}\text { T castaneum } \\
\text { (Tenebrionidae) }\end{array}$ & $\begin{array}{l}\text { S. cerealella } \\
\text { (Gelechiidae) }\end{array}$ & C. ferugineus & $\begin{array}{l}\text { O surinamensis, } \\
\text { (Silvanidae) }\end{array}$ \\
\hline & Coleoptera & Coleoptera & Lepidoptera & $\begin{array}{c}\text { (Laemophloeidae) } \\
\text { Coleoptera }\end{array}$ & Coleoptera \\
\hline & Mean \pm SD & Mean \pm SD & Mean \pm SD & Mean \pm SD & Mean \pm SD \\
\hline Babile & $34.28 \pm 5.94$ & $12.66 \pm 2.38$ & $27.68 \pm 9.01$ & $14.58 \pm 6.27$ & $11.88 \pm 2.06$ \\
\hline Gursum & $31.50 \pm 4.35$ & $14.50 \pm 5.19$ & $26.75 \pm 6.71$ & $18.08 \pm 2.61$ & $8.75 \pm 5.50$ \\
\hline Jijiga & $44.75 \pm 2.98$ & $9.35 \pm 1.46$ & $37.92 \pm 3.26$ & $2.84 \pm 0.53$ & $7.25 \pm 1.25$ \\
\hline Awu-barre & $54.50 \pm 5.00$ & $8.25 \pm 2.50$ & $21.75 \pm 1.50$ & $5.25 \pm 1.50$ & $10.25 \pm 2.5$ \\
\hline
\end{tabular}

calculated as [8].

Insect damaged grain $(\%)=\underline{\text { Number of insect damaged grain } \mathrm{x} 100}$

Total number of grain

Germination test: From each collected grain samples from all districts 400 seed of sorghum and maize seed were taken randomly form each samples then divided in four equal parts and placed in Petridish which was lined with filter paper moistened with distilled water in 100 seed/petridish. Then germinated seed were counted till the $7^{\text {th }}$ day and germination present was calculated.

Data analyses: Data on relative abundance, insect grain damage and germination percentage for each district were summarized and subjected to descriptive statistics analysis and mean and standard deviation were performed using SPSS Ver. 23 statistical package and the result was presented in tables.

\section{Result and Discussion}

\section{Occurrence of storage insect pests in traditional underground pit grain store}

In four assessed districts, two major and three minor species of storage insect pests viz., Maize weevil (Sitophilus zeamais), Angoumois grain moth (Sitotroga cerealella) and flour beetle (Tribolium castenum), Flat grain beetles (Cryptolestes ferugineus) and Saw-toothed grain beetle (Oryzaephilus surinamensis) were recorded (Table 1). Accordingly $\mathrm{S}$ zeamais, had relatively high relative abundance value in all survey districts, comapred to other all districts the highest relative abundance of $S$. zeamais was recorded in Awu-barre and followed by Jigjiga. Low relative abundance figure of $S$. zeamais observed in Babile and Gursum districts. Relatively higher $S$. cerealella relative abundance was observed in Jigjiga which was $37 \%$ followed by Babble and Gursum (Table 1), the lowest was observed in Awu-barre district. S. zeamais and S. cerealella were predominantly occurred and highly abundant in all assesd onfarm grain storages. Minor but potential storage insect pests T. castaneum, C. ferugineus and O. surinamensis were also recorded in comparably low relative abundance in all assessed grain stores. 
Current finding is in agreement with Dubale et al. [2] who reported two major insect pests maize weevil (S. zeamais) and Angoumois grain moth (S. cerealella) in large proportion in traditional grain stores in Ethiopia. Similarly John et al. [9] reported $46.1 \%$ Sitophilus spp relative abundance in traditional grain storages. $\mathrm{S}$ cerealella has been designated as a serious primary pest that mainly attacks maize, wheat and sorghum, both in the field and in stores in central Ethiopia [10]. Minor but potential storage insect pests also recorded across all districts with relatively low abundance thus T. castenum, C. ferugineus and O. surinamensis with mean relative abundance of $11.85 \%, 8.59 \%$ and $10.21 \%$ respectively. Similarly Marryam et al. [11] reported less than five major insects of stored grains particularly stored in traditional storage system. In this study insect grain damage was significant across all districts however the damage was more sever in maize than sorghum. The average insect grain damage was $22.24 \%$ and $31.14 \%$ for sorghum and maize respectively.
Previous studies in other parts of the country reported in the range $20-50 \%$ for different stored grain stored in traditional grain stores $[1,2,12]$. Several factors may have contributed to high grain damage, among the factors crop spices, storage duration, storage type and management practice can influence grain damage by insect pests [13]

\section{Insect grain damage and germination percentage}

High percent of grain damage for both stored items observed across all sampled stores across the districts. Maximum grain damage in sorghum was recorded from Awu-barre district $29.27 \%$ (Table 2). The highest grain damage in maize was recorded in Babile 33.88\%, Gursum 32.47\% and Jigjiga 30.86\%. In all surveyed districts grain damage due to insect were sever in maize compared to sorghum (Table 2). The mean insect damaged grain of sorghum was $23.4 \%$ for all districts were as $28.77 \%$ for maize.

Table 2: Germination and insect grain damge persentage of each sampled destrics

\begin{tabular}{|c|c|c|c|c|c|c|c|c|}
\hline \multirow{2}{*}{ Districts } & \multicolumn{4}{|c|}{ Insect grain damage \% } & \multicolumn{4}{c|}{ Germination \% } \\
\hline & \multicolumn{2}{|c|}{ Sorghum } & \multicolumn{2}{c|}{ Maize } & \multicolumn{2}{c|}{ Sorghum } & \multicolumn{2}{c|}{ Maize } \\
\cline { 2 - 10 } & Mean & $\pm S \mathrm{SD}$ & Mean & \pm SD & Mean & \pm SD & Mean & \pm SD \\
\hline Babile & 22.00 & \pm 6.82 & 33.88 & \pm 3.51 & 72.53 & \pm 5.85 & 63.89 & \pm 4.35 \\
\hline Gursum & 13.33 & \pm 1.52 & 32.47 & \pm \pm 6.61 & 80.49 & \pm 9.01 & 61.67 & \pm 3.61 \\
\hline Jijiga & 24.33 & \pm 7.76 & 30.86 & \pm 3.77 & 71.42 & \pm 10.59 & 65.35 & \pm 17.09 \\
\hline Awubarre & 29.27 & \pm 3.05 & 27.38 & \pm 9.50 & 68.48 & \pm 7.37 & 70.06 & \pm 11.71 \\
\hline
\end{tabular}

The result of the laboratory seed germination test showed that both sorghum and maize grain stored for at least 8-9 month showed mean germination percentage of $72.81 \%$ and $66.96 \%$ respectively (Table 2). Compared to sorghum, maize exhibited relatively low germination percentage across all assessed districts. Highest germination percentage of sorghum was recorded from grain samples collected from Gursum 80.49 followed by Babile $72.53 \%$. Lowest sorghum germination percentage was recorded from Awu-barre 68.48\%. In this study maize grain samples collected from Awu-barre district showed relatively higher germination percentage $70.06 \%$ compared to the other districts and the next higher germination percentage of maize was observed Jigjiga district $65.53 \%$. Other assessed districts showed relatively low germination percentage of maize $63.89 \%$ and $61.67 \%$ for Babile and Gursum districts respectively (Table 2). Factors like grain storage duration, management practice, grain storage type and insect damage can significantly influence germination capacity of stored grain [14].

According to the result in Table 2 sorghum germination percentage was higher than maize the mean germination percentage was $73.23 \%$ and $65.24 \%$ for sorghum and maize respectively. Similar reports by indicted that higher grain damage on those grains stored in traditional grain storages due to primary insect pests $[8,15]$. In current study in all assed districts, maize germination was significantly lower than that of sorghum this could be due to relatively higher infestation and grain damage exhibited in maize led to reduced germination parentage. There result was in agreement with other study reported by Shakeelet al. [16] indicted that insect grain damage reduces grain germination percentage in seeds stored in traditional storage.

\section{Conclusion}

Current finding identified that all assessed 179 pit grain stores exhibited with significant infestation with maize weevil (S. zeamais), Angoumois grain moth (S. cerealella) and flour beetle (T. castenum), flat grain beetles (C. ferugineus) and Sawtoothed grain beetle (O. surinamensis). Among five commonly recorded insect pest two of them namely maize weevil (S. zeamais), angoumois grain moth (S. cerealella) were highly abundant and damaging in major stored items. There were also maximum grain damage and reduced seed germination capacity have been observed in grain samples collected from these traditional underground pit storage system. Therefore, efforts should be initiated on activities those leading to improvement traditional storage system and there by reduction in infestation, grain damage and losses.

\section{Acknowledgement}

The author of this manuscript deeply acknowledges Jigjiga, Awubarre Gurusm and Babile districts crop production department and their experts in assisting the field study. The Authors also acknowledges Jigjiga University Dryland Crops Sciences and its laboratory technicians. 


\section{References}

1. Abraham $T$ (1995) Insects and other arthropods recorded from stored maize in western Ethiopia. African Crop Science Journal 4(3): 339-343.

2. Dubale B, Waktole S, Solomon A, Geremew B, Setu MR (2012) Influence of Agro-ecolog, traditional storage containers and major insect pest on stored maize (Zeamayas L.) in selected woredas of Jima zone. Asian Journal of Plant Science 11: 226-234.

3. Charles A, Midega O, Alice A, Murage W, Jimmy B, et al. (2016) Managing storage pests of maize: Farmers' knowledge, perceptions and practices in western Kenya. Crop Protection 90: 142-149.

4. Gabriel AH, Hundie B (2006) Farmers post-harvest grain management choices under liquidity constraints and impending risks: Implications for achieving food security objectives in Ethiopia. Proceedings of the international association of agricultural Economists Conference, $\mathrm{Au}-$ gust 12-18, Gold Cost, Australia.

5. Togola A, Seck PA, Glitho IA, Diagne A, Adda C, et al. (2013) Economic Losses from Insect Pests Infestation on rice Stored on farm in Benin. Journal of Applied Sciences 13(2): 278-285.

6. Shiferaw T, Dargo F, Osman A (2015) Agro pastoralist Evaluations of Integrated Sorghum Crop Management Packages in Eastern Ethiopia. Advances in Crop Science Technology 3(5):190-195.

7. David R (2007) Insects of stored grain: a pocket reference. ( $2^{\text {nd }}$ edn $)$, CSIRO publishing 150 Oxford Street (PO Box 1139), Collingwood VIC 3066, Australia.

8. Wambugu PW, Mathenge PW, Auma EO, Rheenen HA (2009) Efficacy of traditional maize (Zea mays L.) seed storage methods in Western Kenya. African Journal of Food Agriculture Nutrition and Development. 9:1110-1128.
9. John K, Gudeta W, Sileshib S, Belmainc R, Phosiso S, et al. (2011) Insect pest management practices and pesticidal plant use in the protection of stored maize and beans in Southern Africa. International Journal of Pest Management 57: 41-49.

10. Emana G, Assefa GA (1998) Arthropods pests of stored maize in Sidama zone: Economic importance and management practices. Pest Management Journal of Ethiopia 2: 26-35.

11. Marryam B, Qamar S, Syed MZ, Shafqat S, Tariq A, et al. (2013) Role of storage facilities for insect pest control strategies in Punjab Pakistan. Journal of Stored Products and Postharvest 4: 55-60.

12. Eticha F, Tadesse A (1999) Insect pests of farm-stored sorghum in the Bako area. Pest Management Journal of Ethiopia 3: 53-60.

13. Mustapha B, Mohamed F, Farida B (2011) Survey of insects pest stored and biological control of Trogodermagranarium Evert in Setifian region (North-East of Algeria) Bulletin UASVM Agriculture 68(1).

14. Lemessa F, Bultosa G, Wakgari W (2000) Quality of grain sorghum (Sorghum bicolour L.) Moench stored in traditional underground pits: Case studies in two agroclimatic zones in Hararghe, Ethiopia. Journal of Food Science Technol 37: 238-244.

15. Chattha SH, Hasfalina CM, Mirani BN, Mahadi MR, Lee TS (2016) Food grain losses associated with indigenous storage methods and development of storage facilities for food security. Inter Food Research Journal 23: 57-63.

16. Shakeel H, Che C, Man H, Muhammad RM, Benish NM, et al. (2015) Quality change of wheat grain during storage in a ferro-cement bin. ARPN Journal of Agricultural and Biological Science 10(8): 1990-2614.

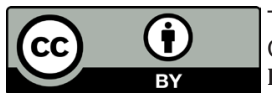

his work is licensed under Creative Commons Attribution 4.0 License DOI:10.19080/ARTOAJ.2018.13.555879

\section{Your next submission with Juniper Publishers} will reach you the below assets

- Quality Editorial service

- Swift Peer Review

- Reprints availability

- E-prints Service

- Manuscript Podcast for convenient understanding

- Global attainment for your research

- Manuscript accessibility in different formats

( Pdf, E-pub, Full Text, Audio)

- Unceasing customer service

Track the below URL for one-step submission https://juniperpublishers.com/online-submission.php 